focus on German Studies.

https://journals.uc.edu/index.php/fogs

(ISSN 1076-5697)

focus

on German Studies

Issue 28 (2021)

Book Review

Meanings of Modern Work in Nineteenth- and Twenty-First-Century German

Literature and Film

by Peter C. Pfeiffer and Nathan T. Tschepik (Eds.), Peter Lang, 2020. VIII, 186 pp.

$\$ 52.95$

Marisol Bayona Roman

The University of Texas at Austin

How to Cite: Roman, Marisol, Bayona. "Book Review: Meanings of Modern Work in Nineteenth-and Twenty-First-Century German

Literature and Film”. focus on German Studies 28, no. 28, 2021, pp. 254-258. DOI: 10.34314/FOGS2021.00021. 


\section{Meanings of Modern Work in Nineteenth- and Twenty-First-Century German Literature and Film}

\section{by Peter C. Pfeiffer and Nathan T. Tschepik (Eds.), Peter Lang, 2020. VIII, 186 pp.}

\section{$\$ 52.95$}

\section{Marisol Bayona Roman}

The present volume was born of an interdisciplinary conference that took place at Georgetown University in April 2016, co-organized by Professor Peter C. Pfeiffer and thenundergraduate Nathan T. Tschepik to explore meanings of modern work in times of disruption. Prompted by the far-reaching impact of technological innovations in the digital age — including the Internet of Things, artificial intelligence, advanced robotics, and the advent of big data - the seven contributions in this volume explore how such rapid progress has profoundly changed, and continues to challenge, established notions of work in German-speaking countries. The role of technology in this disruption, coupled with the lasting influence of the Industrial Revolution on ideas about work, informs the editors' decision to focus on the nineteenth and twenty-first centuries. The volume additionally aims to explore how the humanities can provide some direction in the tumultuous present.

The volume's two halves focus on the nineteenth and twenty-first century, respectively. Despite its foregrounding in the introduction, technology fades into the background in the first half as the contributors focus on the consequences of the Industrial Revolution for meanings of work. In the first essay of the nineteenth-century section, André 
Lottmann demonstrates how Goethe's Wilhelm Meister novels—in particular, Wilhelm Meister's Journeyman Years or the Renunciants—reenact the transition and confrontation between different views of work, from the prioritization of Bildung to the glorification of productive human labor that characterizes modern conceptualizations. Through his analysis of institutions' and characters' fates within their encompassing economic system, Lottmann additionally shows Goethe's growing ambivalence toward Adam Smith's influential ideas of economic liberalism. In the second contribution, Japhet Johnstone uses biographical information, historical context, and theories about the power of language-specifically Hannah Arendt's views of thinking and speaking as work with political implications, J.L. Austin's speech acts and performatives, and Jacques Derrida's and Judith Butler's revisions of Austin-to explain how the court fool in Georg Büchner's satirical play Leonce und Lena illustrates language's potential to undermine an existing regime and introduce new ideas about what qualifies as work. Finally, Peter Meilaender's contribution examines multiple novels by the Swiss author Jeremias Gotthelf and specifically tracks the fate of two characters whose values of hard work and community are ultimately undermined by the growing dominance of dishonest politics. The incorporation of authors' own political engagement in all three contributions conveys literature's potential as a fruitful mode through which to engage with and challenge nineteenth-century economic concepts. These contributions also highlight meanings of work as they manifest and change through the 
relationship between institutions, communities, and individuals, and set the stage for the ensuing discussions of work and disruption in the twenty-first century.

While the entire volume is well-organized, the way in which each contribution in the second half of the volume builds and elaborates on themes discussed in the previous one is especially impressive. In her discussion of three contemporary German novels—namely Ulrich Peltzer's Das bessere Leben, Terézia Mora's Das Ungeheuer, and Thomas von Steinaecker's Das Jahr in dem ich aufhörte mir Sorgen zu machen und anfing zu träumen-Monika Shafi dissects how these novels play with temporality and death to uncover the characters' deep crisis of meaning as a product of neoliberal logic. Echoing issues raised in the first half of the volume, Shafi additionally diagnoses these crises as uniquely personal experiences that inherently preclude any sense of community. Sabine von Dirke's essay elaborates on this lack of community through an expanded conceptualization of technology in the twenty-first century and a comparative analysis of two contemporary essay films. In Harun Farocki's Zum Vergleich, von Dirke identifies a nostalgia for community associated with older technologies still used in other parts of the world. With Carmen Losmann's Work Hard Play Hard, however, von Dirke articulates how immaterial technologies employed in human resource management preclude the development of employees' dignity and effectively undercut any sense of community. The final two chapters broaden the volume's scope further to include philosophical considerations. Martin Jörg Schäfer's essay addresses the modern 
aestheticization of labor and demonstrates how this radical distortion of Nietzsche's

aesthetics serves as an attempt to disguise employers' desire to develop self-optimizing employees. Finally, Michael Festl's philosophical piece considers how meanings of work inevitably change along with their immediate and global contexts and outlines a correspondingly flexible normative theory that considers the ideals of workers affected by technology.

Altogether, this volume highlights the wide-ranging impact of material changes on meanings of modern work and, by foregrounding the preclusion of community and selffulfillment that has followed suit, addresses a sentiment that is already present in the scholarship about work and neoliberalism in the twenty-first century but has not yet been studied in depth. Furthermore, the ingenuity and detailed contextualization of each contribution, coupled with a stylistic and structural clarity that bolsters the cohesion between such diverse perspectives, makes this an accessible collection to scholars outside of German studies. Given its clear style and sound structure, the volume could be utilized to teach graduate students how to compose an article-length project or to show advanced undergraduates how to build an argument with evidence from a primary text. In conclusion, I would highly recommend this volume to literary and film scholars in German studies who focus on the nineteenth and twenty-first centuries, as well as to aspiring scholars starting to try their hand at larger-scale text-based projects. 